\title{
POLITIKK
}

SKANDINAVISK TIDSSKRIFT

FOR INTERNASJONALE STUDIER

Årgang 79, Nummer 2, side 155-165, 2021, ISSN 1891-1757, www.tidsskriftet-ip.no, Publisert mai 2021

\section{Something special? De transatlantiske bånd og deres holdbarhed}

\author{
Niels Byrjalsen \\ Københavns Universitet, Danmark
}

\section{Special Relationships in World Politics: Inter-State Friendship and Diplomacy after the Second World War \\ Kristin Haugevik \\ Routledge, 2018}

\author{
Enduring Alliance: A History of NATO and the Postwar Global Order \\ Timothy A. Sayle \\ Cornell University Press, 2019
}

\section{Sammendrag}

De nære relationer mellem USA og Europa har i årtier været et centralt element $\mathrm{i}$ international politik. Men hvor kommer det transatlantiske forholds holdbarhed og modstandskraft fra? Dette spørgsmål optager mange forskere og aktualiseres $\mathrm{nu}$ af de igangværende forskydninger i verdenspolitikken. Bogessayet diskuterer derfor, hvordan de to bøger Special Relationships in World Politics (Haugevik, 2018) og Enduring Alliance (Sayle, 2019) fremmer vores viden om de bånd, der knytter staterne i det nordatlantiske område. Haugevik undersøger bilaterale amerikansk-britiske og britisk-norske 'specielle forhold', mens Sayle ser nærmere på det multilaterale samarbejde i NATO. De tilbyder begge interessante teoretiske argumenter om samspillet mellem diplomatisk praksis og nationale politiske dynamikker samt imponerende empiriske analyser, som underbygger deres pointer. De to bøger rejser samtidig også nye vigtige spørgsmål, herunder

\footnotetext{
^Kontaktinformasjon: Niels Byrjalsen, e-post: niby@ifs.ku.dk

(C2021 Niels Byrjalsen. This is an Open Access article distributed under the terms of the Creative Commons Attribution 4.0 International License (http://creativecommons.org/licenses/by/4.0/), allowing third parties to copy and redistribute the material in any medium or format and to remix, transform, and build upon the material for any purpose, even commercially, provided the original work is properly cited and states its license.

Citation: Byrjalsen, N. (2021). Something special? De transatlantiske bånd og deres holdbarhed. Internasjonal Politikk, 79(2), 155-165. http://dx.doi.org/10.23865/intpol.v79.2758
} 
om de indbyggede spændinger i liberale normer og værdier samt om betydningen af tillid for det transatlantiske forholds holdbarhed.

Nøgleord: det transatlantiske forhold • NATO • tillid • diplomati • international orden

\section{Indledning}

Det transatlantiske hus står på usikker grund. Vidtrækkende forandringer i de globale magtforhold bringer de liberale demokratier i defensiven. De må nu forsvare sig mod undergravende virksomhed og påvirkningskampagner udefra (Breitenbauch \& Byrjalsen, 2019). Indefra svækkes fundamentet af demokratisk forfald og modstand mod den liberale orden (Adler-Nissen \& Zarakol, 2020). Brexit og Trumpadministrationen er de vigtigste events, men tendensen er bredere, og årsagerne dybere. Derfor trænger to spørgsmål sig på. Hvor holdbare er de transatlantiske bånd? Og hvordan fastholdes og fornys disse bånd i praksis?

Forskningen i international politik har længe beskæftiget sig med det transatlantiske forhold og dets centrale position i den globale orden. Årene efter Den Kolde Krigs afslutning var gennemsyret af optimisme. Det afspejlede sig ikke mindst i konstruktivistiske teorier og analyser. Betydningen af normer og deres udbredelse særligt de fælles demokratiske normer, som ifølge mange iagttagere var hjørnestenen i forholdet imellem USA og Europa - blev undersøgt vidt og bredt (Finnemore \& Sikkink, 1998; Risse-Kappen, 1995). Samtidig blev teorien om sikkerhedsfællesskaber (security communities) karakteriseret af 'we-feeling' en central fortolkningsramme for at forstå, hvad der binder NATO-alliancen og de liberale demokratier sammen (Adler \& Barnett, 1998). Efter årtusindeskiftet blev analyserne af det transatlantiske forhold og dets fremtidsperspektiver mere kritiske og skeptiske. Nogle mente ligefrem, at forskellene på tværs af Atlanten - med 'amerikanere fra Mars og europæere fra Venus' - gjorde en langsigtet fastholdelse af den tætte relation stort set umulig (Kagan, 2002). I hvert fald viste den globale krig mod terror, især splittelsen omkring Irak-krigen, samt handlingslammelsen i klimapolitikken og den økonomiske krise i slutningen af 2000'erne, at Europa på godt og ondt er spundet ind i USA's globale magtstrukturer. Af samme grund er hegemoni og imperium i de senere år blevet hyppigt anvendte analysekategorier for at forstå den internationale ordens dynamikker på makroniveau (Ikenberry, 2011; Nexon \&Wright, 2007). Sideløbende har der været voksende interesse i, hvad der foregår på mikroniveau i diplomatiet, hvor uenigheder skal håndteres, og samarbejde realiseres (Adler-Nissen \& Pouliot, 2014; Sending et al., 2015). De to bøger, der behandles i dette essay, lægger sig på hver sin måde i forlængelse af dette nye fokus på den diplomatiske praksis. Haugevik gør det direkte, Sayle mere indirekte.

Selvom de seneste årtiers forskning har medført en væsentlig teoriudvikling, der hjælper med at forstå forholdet imellem Europa og USA, er det fortsat nødvendigt 
med nye og forbedrede svar. Det skyldes ikke kun manglerne i den eksisterende viden, men også at verden bevæger sig og rejser nye spørgsmål. Eksempelvis havde de færreste for få år siden forestillet sig en amerikansk trussel om at trække sig fra NATO, men med Trump som præsident blev det en realitet. Det transatlantiske forhold er med andre ord en kompliceret og foranderlig størrelse, som påkalder sig fortsat akademisk interesse.

De to bøger tilbyder to forskellige veje til at forstå forholdet bedre. Haugevik fokuserer på bilaterale specielle forhold (special relationships). Sayle ser på det multilaterale samarbejde i NATO. Begge går historisk til værks og åbner dermed et rum for bedre at forstå de dynamikker, som også i dag er på spil imellem europæerne og amerikanerne. I essayets afsluttende del udfoldes nogle af disse dynamikker med et fokus på behovet for at gentænke de liberale demokratiers position i den globale politik samt vigtigheden af tillid for det transatlantiske forholds levedygtighed.

\section{Specielle forhold som praktiske fællesskaber og diskursive repræsentationer}

Forestillingen om specielle forhold imellem stater og nationer er almindelig kendt men underbelyst i forskningen. Haugevik tager udfordringen op og giver overbevisende svar på, hvad specielle forhold er, hvordan de skabes, og hvilken betydning de har. Disse spørgsmål undersøges gennem et imponerende omfangsrigt komparativt studie af amerikansk-britiske og britisk-norske relationer, begge fra Anden Verdenskrigs afslutning til i dag.

Bogens teoretiske argument er intuitivt appellerende. Haugevik mener, at specielle forhold bør opfattes som relationelle identitetskonstruktioner, der udvikles i samspillet imellem indenrigspolitiske repræsentationer af det pågældende forhold som 'specielt' og udenrigspolitiske interaktionsmønstre, som underbygger eller udfordrer disse repræsentationer. Dette foregår i en social proces, der på baggrund af Goffmans (1959) velkendte sondring knytter anerkendelse af forholdets specielle karakter på 'frontstage' (i det offentlige og officielle rum) med tillidsskabelse blandt praktikere på 'backstage' (det mere private og uofficielle samspil). Dermed taler Haugevik også for, at specielle forhold ikke ses som en generisk kategori med særegne karakteristika, der kan kortlægges, men snarere som særlige manifestationer af socialt konstruerede forhold imellem stater (20). Det er med andre ord et åbent spørgsmål, hvornår interstatslige forhold er (eller kan være) specielle forhold, da det er staterne selv, der gør dem specielle - dels i deres diskursive repræsentationer af identitet, dels i hverdagens praksis.

Koblingen af diskurs og praksis i et samlet teoretisk apparat er ikke ny. Eksempelvis anvender Koschut (2016) en lignende kobling i sin analyse af sikkerhedsfællesskabers disintegration. Haugeviks tilgang er således en afprøvet middle ground, der kombinerer et poststrukturalistisk syn på relationelle identiteter (Hansen, 2006) med praksisteoretikernes fokus på praktiske interaktioner (Adler \& Pouliot, 2011; Bueger \& Gadinger, 2018). Mange med et - i bred forstand - konstruktivistisk udgangspunkt 
vil kunne se fornuften i teoretiseringen og genkende dens grundlæggende arkitektur. Tilgangen gør imidlertid også, at argumentet bevæger sig behændigt uden om vanskelige ontologiske spørgsmål om det grundlæggende forhold imellem (material) praksis og (immateriel) diskurs.

I bogens empiriske del omsættes det teoretiske udgangspunkt til interessante analytiske pointer. Selvom forholdet imellem USA og Storbritannien - 'The Special Relationship' - er analyseret mange andre steder, giver Haugeviks historiske gennemgang en nyttig fortolkningsramme, der understreger, hvorfor og hvordan det har været specielt så længe, som det har. Analysen identificerer 'venskab', 'partnerskab' og 'patron-klient' som de dominerende repræsentationer af forholdet i den politiske diskurs (58). De tre repræsentationer er kontinuerligt til stede i hele perioden, men varierer i styrke og relevans i samspil med diverse begivenheder og kriser samt forandringerne af den internationale kontekst. Den praktiske interaktion ved de profilerede amerikansk-britiske topmøder og i de mere rutineprægede og 'usynlige' netværk af amerikanere og briter, der samarbejder på ambassader, på permanente repræsentationer, i militære hovedkvarterer og andre steder, er snævert forbundet med reproduktionen af de diskursive repræsentationer. Eksempelvis viser Haugevik, hvordan bilaterale møder imellem den britiske premierminister Attlee og den amerikanske præsident Truman i 1950 baserede sig på 'venskab'-repræsentationen - og at rapporter om mødernes venskabelighed direkte styrkede denne repræsentation i den efterfølgende politiske diskurs (62). I andre tilfælde er det i højere grad relationerne på backstage, der har betydning for forholdets stabilitet. F.eks. berettes det fra en kilde, at det under Suez-krisen i 1956-1957 var britiske diplomater på lavere niveauer (working level diplomats), der holdt relationen til Washington kørende, da man ikke ville acceptere kontakt på 'højere niveauer' (106-107).

Det britisk-norske forhold er på samme måde konstrueret i koblingen af diskurs og praksis. Men casen er også interessant, da den illustrerer, at teorien kan bruges mere generelt til at forstå specielle forhold imellem stater - og altså ikke kun ved 'The Special Relationship'. Haugevik fremhæver fire repræsentationer i den norske politiske debat: 'frelser', 'ledestjerne', 'langt fra hinanden' (poles apart) og 'én ven blandt mange' (118). I årtierne efter Anden Verdenskrig var de to førstnævnte repræsentationer dominerende, hvilket afspejlede sig og blev forstærket i praksis, hvor britiske diplomater havde privilegeret adgang til det norske politiske system. Over tid er forholdet dog blevet mindre specielt. Pointen er, at dette i høj grad skyldes, at forholdet ikke er blevet tilstrækkeligt vedligeholdt i diskurs og praksis. Haugevik kalder denne udvikling benign neglect. Dermed står det britisk-norske forhold i kontrast til det amerikansk-britiske forhold, som konsekvent er blevet reproduceret som noget specielt frem til i dag. Senest har Brexit dog genoplivet forestillingen om et specielt forhold imellem Storbritannien og Norge, der nu begge står uden for EU (Haugevik, 2017). På den måde viser casen også, at specielle forhold ikke er set in stone, men snarere er noget, der kan forsvinde og opstå igen, hvis omstændighederne fordrer det. 
Hvorvidt forholdet efter Brexit rent faktisk bliver trukket i en mere speciel retning, er fortsat uklart. Det afhænger - i tråd med bogens hovedargument - af, hvad britiske og norske praktikere gør.

Den komparative analyse anskueliggør ikke blot specielle forhold på en brugbar måde, men rejser også nye spørgsmål om de transatlantiske bånd og deres fastholdelse. For det første kan frontstage-backstage-sondringen udfoldes mere. Hvor går grænsen imellem de to? Er bilaterale topmøder f.eks. front- eller backstage? $\mathrm{Og}$ hvordan skal vi forstå samspillet mellem de to 'scener', når det ikke kun handler om at skabe en national identitet, men også om at reproducere praktiske samarbejdsrelationer? Dertil kommer Haugeviks teoretiske valg om at placere anerkendelse på frontstage og tillid på backstage, som ikke forklares nærmere. Måske er det muligt at sige noget mere generelt om de omstændigheder og betingelser, der gør henholdsvis anerkendelse og tillid vigtige i reproduktionen af specielle forhold, herunder i forbindelse med kriser på tværs af Atlanten.

For det andet åbner Haugeviks analyse for en bredere diskussion af, hvad specielle forhold kan være - og hvordan begrebet knytter sig til andre termer som venskab (Koschut \& Oelsner, 2014) og slægtskab (Haugevik \& Neumann, 2019). I denne sammenhæng er bl.a. betydningen af individuelle politiske ledere og topdiplomater interessant. Kan individer på centrale poster gennem deres personlige venskaber have større betydning for fastholdelsen af interstatslige bånd end mere tvetydige forestillinger om slægtskab imellem samfund og befolkninger? Og hvordan skal vi forstå betydningen af individer som den amerikanske præsident Trump, der går imod alle de normer og praksisser, der normalt sikrer både anerkendelse og tillid i det transatlantiske forhold? Underminerer sådanne ledere specielle forhold - eller medfører de snarere en slags mutation, hvor forholdet fortsat er specielt, men på en anden måde?

\section{NATO som grundlaget for det transatlantiske forhold}

Det multilaterale samarbejde i NATO-alliancen tilbyder et andet afsæt for at forstå det transatlantiske forhold og de seneste transatlantiske brydninger. Sayles grundlæggende ærinde er at undersøge, hvor NATOs holdbarhed (endurance) stammer fra - et spørgsmål, som forskningen har forskellige svar på (Thies, 2009; Webber \& Hyde-Price, 2016). Dette gøres ved hjælp af en indsigtsrig nyfortolkning af NATOs historie fra slutningen af 1940'erne til starten af 1990'erne, der trækker på et omfattende kildemateriale. Bogen er velskrevet og fokuserer på den historiske fremstilling, mens teoretiske argumenter og refleksioner langt hen ad vejen forbliver implicitte. Dermed henvender den sig også til et bredere publikum uden for akademia.

Ligesom Haugevik beskæftiger Sayle sig med, hvordan tætte bånd imellem stater og deres repræsentanter skabes, fastholdes og forandres over tid. Det centrale argument er, at NATO har været omdrejningspunktet, der har tilladt alskens transatlantiske relationer (politiske, økonomiske, kulturelle, teknologiske, etc.) at 
blomstre - snarere end blot en organisatorisk manifestation af et dybereliggende transatlantisk forhold. NATOs holdbarhed er fra dette perspektiv et resultat af, at generationer af ledere og diplomater i både Europa og Nordamerika har opfattet alliancens rolle på denne måde og prioriteret den over andre hensyn (9). Sayle kobler dermed realismens antagelser om staters interessevaretagelse og søgen efter magt og sikkerhed med et analytisk fokus på betydningen af diplomatisk og alliancepolitisk praksis. Hvor de praktiske interaktioner for Haugevik understøtter konstruktionen af specielle forhold, fastholder de hos Sayle en bestemt opfattelse af NATOs karakter og essentielle rolle i transatlantisk sikkerhed.

Bogens empiriske tyngepunkt er 1950'erne-1970'erne. Især det til tider vanskelige diplomatiske spil mellem den franske præsident de Gaulle og skiftende amerikanske og britiske ledere granskes i detaljer. Fra fransk side var der utilfredshed med at være tredjehjul i alliancen, og Sayle fremhæver bl.a. et interessant memorandum fra 1958, hvori de Gaulle fremlagde sit ønske om et trebenet partnerskab med USA og Storbritannien (50). Selvom forslaget i første omgang blev affejet, kom det til at præge de følgende års diskussioner om NATOs udvikling. I 1966 blev konsekvensen, at Frankrig trak sig ud af NATOs integrerede militære kommando, men forblev alliancemedlem - og dermed understregede alliancens fundamentale betydning (119). Eksemplet indikerer, med Haugeviks centrale begreb in mente, at specielle forhold (det amerikansk-britiske) ikke skabes $i$ et vakuum, men snarere interagerer med alliancerelationer (NATOs multilateralisme) og andre specielle forhold (det amerikansk-britisk-franske som vestlige allierede i Anden Verdenskrig). Denne slags komplicerede transatlantiske relationer findes også i dag, herunder for Storbritannien, der efter Brexit forsøger at finde sine forsvars- og sikkerhedspolitiske ben imellem USA og Frankrig-Tyskland, imellem NATO og EU og imellem unilaterale, bilaterale og multilaterale interesser (Johnson \& Matlary, 2019).

En anden bemærkelsesværdig pointe i bogen er, at NATOs største trussel ifølge Sayle aldrig har været ekstern og militær, men snarere har været politisk og er kommet indefra: faren for politisk disintegration af de allierede (2). Fra dette perspektiv har NATO-landenes ledere og diplomater kontinuerligt søgt at beskytte alliancen mod demokratiet selv, dvs. mod lunefulde vælgere og opportunistiske politikere, der kunne finde på at forfølge en politik, som man i sidste ende frygtede ville underminere det transatlantiske fællesskab. Som den historiske gennemgang i bogen viser, var denne udfordring betydelig under Den Kolde Krig, hvor Sovjetunionen med subversion (undergravende virksomhed) og politisk pres forsøgte at påvirke både beslutningstagere og befolkninger i Europa og Nordamerika. Pointen om, at den vigtigste trussel kommer indefra, men ofte hjælpes på vej udefra, forekommer også særdeles relevant i dag. Ruslands påvirkningskampagner mod amerikanske og europæiske valg og den amerikanske præsident Trumps angreb på troværdigheden af NATOs kollektive forsvarspagt (artikelV) er blot de mest åbenlyse eksempler på problemstillingens aktualitet.

Samlet indeholder bogen altså både tankevækkende (om end ganske implicitte) teoretiske pointer og grundig historisk analyse. Akilleshælen er imidlertid den 
manglende kobling imellem teori og empiri. Som læser må man selv knytte trådene, og det skaber en vis usikkerhed omkring hovedargumenterne og analysens bredere implikationer for forståelsen af transatlantisk sikkerhed. Eksempelvis synes politisk integration ikke kun at bero på forsvaret mod underminerende kræfter, men også på den aktive sikkerhedsliggørelse af forskelligartede trusler, som fastholder alliancens centrale position i det transatlantiske fællesskab (Hellmann et al., 2014).

Omvendt giver de åbne konklusioner også anledning til at tænke videre over de spørgsmål, som Sayle stiller. Ikke mindst bliver det væsentligt at overveje noget, der ikke længere blot kan affejes som rendyrket spekulation, nemlig hvad der ville ske, hvis USA på et tidspunkt trak sig ud af NATO. Hvor lang tid ville beslutningens implementering tage? Kunne den omgøres? Ville NATO meningsfuldt kunne fortsætte som alliance uden USA? Ville USA opbygge alternative alliancer i Europa? Hvordan ville de europæiske stormagter Tyskland, Frankrig og Storbritannien reagere? Kan forskningen anskueliggøre scenariet, f.eks. gennem andre eksempler på alliancers sammenbrud? Sayle berører kort emnet på bogens allersidste sider og betoner risikoen for et langt mere splittet Europa, hvis NATO ikke længere er der til at pacificere demokratiets skyggesider (247-248). Hvor stor denne risiko er, melder historien ikke noget om, ej heller om EU har noget at skulle have sagt.

\section{Identitet, tillid og den diplomatiske praksis: Kan de transatlantiske bånd fastholdes og fornys?}

Det transatlantiske forhold har i mere end 70 år været en definerende faktor i international politik. De to bøger, der undersøges her, leverer på hver sin måde en del af forklaringen på denne langvarighed og stabilitet. Haugevik viser, hvordan specielle forhold (re)produceres i samspillet mellem diskursive repræsentationer og diplomatisk praksis - og at denne proces er med til at knytte landene i det nordatlantiske område sammen. Sayle tydeliggør, hvordan NATO-landenes ledere og diplomater igen og igen har prioriteret alliancens beståen over andre hensyn. Det er samlet set væsentlige bidrag til forskningen, der styrker forståelsen af det transatlantiske forholds holdbarhed.

Bøgerne peger også fremad. Både Haugevik og Sayle illustrerer betydningen af backstage i international politik. En stor del af de ting, som i praksis fastholder det transatlantiske forhold, foregår på backstage, dvs. i et rum, hvor politiske ledere, diplomater og andre kan interagere uofficielt, uformelt, privat osv. Men deri ligger også en spænding, særligt i lande med en stærk demokratisk kultur, fordi der samtidig er et legitimt krav om transparens, regelstyring og folkets kontrol med magthaverne, inklusive i udenrigspolitikken. Dertil kommer udviklingen i informationsteknologi, bl.a. i form af sociale medier, der udfordrer og transformerer mulighederne for backstage-interaktion. Det er med andre ord en vanskelig balancegang at gå, hvis backstage skal gentænkes som en legitim og effektiv del af udenrigspolitikken. 
Derudover understreger Haugevik og Sayle også, hvor kompliceret spørgsmålet om det transatlantiske forhold i realiteten er. Forholdet kan både finde udtryk i bilaterale relationer som det specielle forhold mellem USA og Storbritannien og i multilaterale kontekster som NATO, hvor et større fællesskab tilgodeses. Men hvor meget fylder henholdsvis det bilaterale og det multilaterale aspekt af det transatlantiske forhold, historisk og aktuelt? Samtidig indikerer de to bøger, at både tillid, magt og fælles normer og værdier er afgørende for, at de transatlantiske bånd varer ved. Det er imidlertid ikke klart, hvordan disse faktorer præcis bidrager til at fastholde og forny båndene på tværs af Atlanten - og hvordan de står i relation til hinanden. Endelig er det ikke givet, hvordan forholdet udvikler sig, i takt med at multipolariteten flytter vægten i verdenspolitikken fra Europa og Mellemøsten mod Asien - en situation, der er markant anderledes end den historiske periode, som Haugevik og Sayle analyserer.

I denne sammenhæng er særligt to udviklinger vigtige at holde sig for øje. For det første står det transatlantiske fællesskab midt i en intensiveret global identitetskamp om normer og værdier. Selvom bl.a. Allan et al. (2018) påpeger, at der fortsat er international støtte til den neoliberale, demokratiske og vestligt dominerede orden, går tendensen i retning af et mere broget billede. Kina og Rusland har blandet markedsøkonomi med nationalisme og stram statsstyring, og det har indlejret dem i den globale økonomi og forøget deres indflydelse. De repræsenterer på hver sin måde alternative visioner for den internationale orden (Kaczmarski, 2017). De antiliberale stormagters nye magtposition udfordrer demokratiet globalt set. Det kommer eksempelvis til udtryk i den bremseklods, der i det seneste årti er blevet sat for menneskerettighedsdagsorden i FN-regi, herunder princippet om et responsibility to protect. Det viser sig også i den vedholdende demokratiske tilbagegang i mange lande (Freedom House, 2020). Politiske hybridformer, der blander demokratiske og udemokratiske styreformer, normaliseres, samtidig med at magthavere kan finde politisk og militær støtte samt økonomiske investeringer ved at samarbejde med Kina og Rusland. Udviklingen udfordrer også sammenhængskraften i det transatlantiske område, hvor fremmede aktører aktivt søger at destabilisere de politiske systemer og processer i Europa og Nordamerika - og derved skabe intern splid i og imellem de liberale demokratier (Breitenbauch \& Byrjalsen, 2019; Wigell, 2019). Denne problemstilling er især udfordrende, fordi det liberale demokrati har vist svaghedstegn og hidtil ikke har leveret de nødvendige løsninger i forhold til bl.a. klimaforandringer, migration, stabilisering og demokratisering af svage stater, voksende ulighed samt regulering af finansielle markeder og big tech.

For de europæiske og nordamerikanske stater indebærer en fastholdelse og fornyelse af de transatlantiske bånd derfor et behov for at genfinde - eller måske snarere gentænke - hvad det vil sige at være liberale demokratier i international politik. Den kollektive identitet blandt de liberale demokratier, som fremhæves i litteraturen om det transatlantiske sikkerhedsfælleskab (Adler \& Barnett, 1998), kan ikke blot tages for givet. Den er derimod noget, som forhandles og produceres i praksis. Det 
betyder også, at den kan forandres eller reformeres. Særligt væsentligt bliver det, om man kan skabe en ny fælles forståelse, der på tidssvarende vis kan knytte det liberaldemokratiske tankesæt - og den dertilhørende selvopfattelse - med magtens sprog og politik. Forestillingerne om EU som normativ magt (Manners, 2002), amerikansk blød magt (Nye, Jr., 2004) og liberalt hegemoni (Ikenberry, 2011) søger alle at integrere magt og identitet. Der er med andre ord et begrebsapparat at bygge på. Men som et felles transatlantisk projekt er det fortsat uklart, hvordan de liberale demokratier kan føre en udenrigspolitik, der effektivt bringer dem ud af defensiven i den globale kamp om normer og værdier.

Den anden udvikling er forbundet hermed, men handler om de interne uenigheder og stridigheder, som forøges parallelt med den eksterne identitetskamp. Sayles pointe om, at den største trussel mod NATO kommer indefra, forekommer lige så relevant i det bredere spørgsmål om det transatlantiske forholds stabilitet og holdbarhed. Forholdet præges i tiltagende grad af identitetskriser, dvs. kriser, der bunder i uenighed om, hvori det fælles består. Disse kriser foregår både inden for og imellem de transatlantiske stater. Præsident Trumps angreb på demokratiske institutioner, multilateralisme, frihandel og den regelbaserede orden, og den europæiske afstandtagen til USA under hans ledelse, er det seneste tydelige eksempel. Tendensen er dog mere generel (Riddervold \& Newsome, 2018), og den må forventes at fortsætte, da der er indbyggede spændinger i det liberale demokrati, der sættes i spil i en mere globaliseret og integreret verden, eksempelvis imellem frihed og sikkerhed, styring og demokratisk legitimitet, progressiv og traditionel kultur samt nationalt og internationalt ansvar.

De voksende uenigheder om normer og værdier - og de hyppigere identitetskriser har den implikation, at andre faktorer bliver vigtigere $i$ forhold til at binde de transatlantiske stater sammen. Som især Haugevik antyder, er tillid afgørende i denne kontekst. Tillid kan stabilisere relationer, når disse rammes af kriser og splittelse, særligt hvis tilliden er stærkt indlejret i institutioner og går på tværs af forskellige statslige og samfundsmæssige aktører. Den fungerer som 'social lim' (Govier, 1997; Putnam, 2000). Samtidig er tillid vigtig, når det handler om at fremme internationalt samarbejde (Elhardt, 2015; Rathbun, 2011). Det indebærer også samarbejde, der kan håndtere og måske endda afslutte internationale kriser. Tillid er dermed af central - om end ofte overset - betydning for det transatlantiske forholds levedygtighed. Denne betydning vokser med al sandsynlighed, i takt med at den amerikanske magt formindskes, og den fælles identitet bliver sværere at bruge som fast holdepunkt. Men tillid kommer ikke af sig selv. Den skal oparbejdes og produceres med et vedholdende fokus og praktisk arbejde, især blandt politiske ledere og diplomater.

Dermed har Haugevik og Sayle en pointe, når de fremhæver den fundamentale rolle, som diplomatiets praktiske interaktion spiller for de transatlantiske bånd. For alle, der søger at forstå de forandringer, som det transatlantiske forhold gennemgår og de udfordringer, det står over for - er de to glimrende bøger derfor et godt sted at starte. 


\section{Om forfatteren}

Niels Byrjalsen er ph.d.-studerende ved Institut for Statskundskab på Københavns Universitet. Hans ph.d.-projekt undersøger sammenhængen imellem tillid og international orden i relation til det transatlantiske forhold. Derudover forsker han i stormagtspolitik og subversive aktiviteter i gråzonen mellem krig og fred.

\section{Referencer}

Adler, E. \& Barnett, M. (Red.) (1998). Security communities. Cambridge University Press.

Adler, E. \& Pouliot, V. (Red.) (2011). International practices. Cambridge University Press.

Adler-Nissen, R. \& Pouliot, V. (2014). Power in practice: Negotiating the international intervention in Libya. European fournal of International Relations, 20(4), 889-911.

Adler-Nissen, R. \& Zarakol, A. (2020). Struggles for recognition: The liberal international order and the merger of its discontents. International Organization, first view.

Allan, B. B., Vucetic, S. \& Hopf, T. (2018). The distribution of identity and the future of international order: China's hegemonic prospects. International Organization, 72(4), 839-869.

Breitenbauch, H. \& Byrjalsen, N. (2019). Subversion, statecraft and liberal democracy. Survival, 61(4), 31-41.

Bueger, C. \& Gadinger, F. (2018). International practice theory, 2nd edition. Palgrave Macmillan.

Elhardt, C. (2015). The causal nexus between trust, institutions and cooperation in international relations. fournal of Trust Research, 5(1), 55-77.

Finnemore, M. \& Sikkink, K. (1998). International norm dynamics and political change. International Organization, 52(4), 887-917.

Freedom House. (2020). Freedom in the world 2020: A leaderless struggle for democracy. https://freedomhouse.org/ report/freedom-world/2020/leaderless-struggle-democracy.

Goffman, E. (1959). The presentation of self in everyday life. Doubleday.

Govier, T. (1997). Social trust and human communities. McGill-Queen's University Press.

Hansen, L. (2006). Security as practice: Discourse analysis and the Bosnian War. Routledge.

Haugevik, K. M. (2017). Hva betyr brexit for utenforlandet Norge? Internasjonal Politikk, 75(2) 152-166.

Haugevik, K. M. \& Neumann, I. B. (red.) (2019). Kinship in international relations. Routledge.

Hellmann, G., Herborth, B., Schlag, G. \& Weber, C (2014). The west: A securitising community? fournal of International Relations and Development, 17(3), 367-396.

Ikenberry, G. J. (2011). Liberal leviathan: The origins, crisis, and transformation of the American world order. Princeton University Press.

Johnson, R. \& Matlary, J. H. (Red.) (2019). The United Kingdom's defence after Brexit: Britain's alliances, coalitions, and partnerships. Springer International Publishing.

Kaczmarski, M. (2017). Non-western visions of regionalism: China's new silk road and Russia's Eurasian economic union", International Affairs, 93(6), 1357-1376.

Kagan, R. (2002). Power and weakness. Policy Review, June-July 2002, Hoover Institution.

Koschut, S. (2016). Normative change and security community disintegration: Undoing peace. Palgrave Macmillan.

Koschut, S. \& Oelsner, A. (Red.) (2014). Friendship and international relations. Palgrave Macmillan.

Manners, I. (2002). Normative power Europe: A contradiction in terms? FCMS: Fournal of Common Market Studies, 40(2), 235-258.

Nexon, D. H. \& Wright, T. (2007). What's at stake in the American empire debate. American Political Science Review, 101(2), 253-271.

Nye, Jr., J. S. (2004). Soft power: The means to success in world politics. PublicAffairs.

Putnam, R. D. (2000). Bowling alone: The collapse and revival of American community. Simon \& Schuster.

Rathbun, B. C. (2011). Trust in international cooperation: International security institutions, domestic politics and American multilateralism. Cambridge University Press.

Riddervold, M. \& Newsome, A. (2018). Transatlantic relations in times of uncertainty: Crises and EU-US Relations. Fournal of European Integration, 40(5), 505-521.

Risse-Kappen, T. (1995). Democratic peace - warlike democracies? A social constructivist interpretation of the liberal argument. European fournal of International Relations, 1(4), 491-517. 
Sending, O. J., Pouliot, V. \& Neumann, I. B. (Red.) (2015). Diplomacy and the making of world politics. Cambridge University Press.

Thies, W. J. (2009). Why NATO endures. Cambridge University Press.

Webber, M. \& Hyde-Price, A. (Red.) (2016). Theorising NATO: New perspectives on the Atlantic alliance. Routledge.

Wigell, M. (2019). Hybrid interference as a wedge strategy: A theory of external interference in liberal democracy. International Affairs, 95(2), 255-275.

\section{Abstract in English \\ Something special? The transatlantic ties and their endurance}

For several decades, the close relationship between the United States and Europe has been a key aspect of international politics. But what are the sources of the endurance and resilience of transatlantic ties? This question preoccupies researchers, and its salience is growing in light of current shifts in world politics. Accordingly, the book essay discusses how the two books Special Relationships in World Politics (Haugevik, 2018) and Enduring Alliance (Sayle, 2019) contribute to our knowledge about the international ties of the North Atlantic area. Haugevik examines bilateral American-British and British-Norwegian 'special relationships', while Sayles studies multilateral cooperation in NATO. They both offer interesting theoretical arguments about the interplay between diplomatic practice and national political dynamics. Moreover, they provide impressive empirical analyses to support their claims. At the same time, the two books raise new important questions, e.g. about the built-in tensions in liberal norms and values as well as about the significance of trust for enduring transatlantic ties.

Keywords: transatlantic relations $\cdot \mathrm{NATO} \cdot$ trust $\cdot$ diplomacy $\cdot$ international order 